\title{
Advances in nanotechnology and the benefits of using cellulose nanofibers in animal nutrition
}

\author{
Geovane Rosa de Oliveira (D), Carla de Andrade (iD, Cristina Santos Sotomaior (iD and Leandro Batista Costa (iD) \\ Graduate Program in Animal Science, School of Medicine and Life Sciences, Pontifícia Universidade Católica do Paraná, \\ PUCPR, Curitiba - PR, Brazil. \\ Corresponding author: Leandro Batista Costa, e-mail: batista.leandro@pucpr.br \\ Co-authors: GRO: geovanebex@hotmail.com, CA: carlazoobr@yahoo.com.br, CSS: cristina.sotomaior@pucpr.br \\ Received: 23-06-2021, Accepted: 22-09-2021, Published online: 03-11-2021
}

doi: www.doi.org/10.14202/vetworld.2021.2843-2850 How to cite this article: de Oliveira GR, de Andrade C, Sotomaior CS, Costa LB (2021) Advances in nanotechnology and the benefits of using cellulose nanofibers in animal nutrition, Veterinary World, 14(11): 2843-2850.

\begin{abstract}
The production of cellulose nanofibers promotes the utilization of plant residues that are generated in agro-industries during food processing. The utilization of these plant by-products reduces environmental contamination. Cellulose nanofibers are used in several sectors, including the drug, food, and animal nutrition industries. Many sources of nanofibers used in animal diets can be used as potential fiber substitutes after being processed to improve efficiency. For instance, including nanometric particles of plant fibers $(<100 \mathrm{~nm})$ in animal feed may provide excellent physical properties such as high reactivity, a large surface area, and improved nutrient absorption from the diet. Nanotechnology improves the characteristics of fibers that are important for gastrointestinal transit and their utilization as energy sources and substrates for microbial fermentation in the digestive tract of animals. Nanofibers can improve the synthesis of volatile fatty acids and the blood lipid profile, with positive effects on the intestinal health of animals. Moreover, in vitro and in vivo studies have demonstrated promising effects in reducing blood glucose levels without toxic effects on the body. Supplying nanofibers in the diet improve animal performance, increase productivity, and work toward a more sustainable economic development of agribusinesses. The quality of animal products such as meat, milk, and eggs is also reported to be improved with the inclusion of nanominerals in the feed. Overall, the application of nanotechnology to harness the by-products of agro-industries can increase economic viability and sustainability in animal production systems. Therefore, this review presents a current survey on the main research and advances in the utilization of nanotechnology, focusing on cellulose nanofibers in animal feed to improve animal performance.
\end{abstract}

Keywords: animal performance, animal production, coproduct, fibers, nanocellulose.

\section{Introduction}

Many currently available products contain materials in nanometric dimensions, such as carbon nanotubes or synthetic amorphous silica, and several others, such as cellulose nanomaterials are being developed. Cellulose is the most abundant semi-crystalline polymer in nature; it covers a wide spectrum of structures with different shapes, sizes, and chemical surfaces [1]. Nanofibers (NFs) are stable nanometric structures corresponding to 1 billionth of a meter $\left(1 \mathrm{~nm}=10^{-9} \mathrm{~m}\right)$ with dimensions less than $100 \mathrm{~nm}$, yet greater in length. Nanofibers can be obtained from various cellulosic plant sources by mechanical, chemical, or enzymatic methods [2,3], for producing materials with increased surface areas, reactivity [4], and absorption. Cellulose nanofibers have several applications in the food, packaging, and biomedicine industries. In addition to being obtained from biodegradable natural sources, their production

Copyright: de Oliveira, et al. Open Access. This article is distributed under the terms of the Creative Commons Attribution 4.0 International License (http://creativecommons.org/licenses/ by/4.0/), which permits unrestricted use, distribution, and reproduction in any medium, provided you give appropriate credit to the original author(s) and the source, provide a link to the Creative Commons license, and indicate if changes were made. The Creative Commons Public Domain Dedication waiver (http:// creativecommons.org/publicdomain/zero/1.0/) applies to the data made available in this article, unless otherwise stated. and processing is low cost. The global nanocellulose (NC) market is estimated to grow by more than $18 \%$ by 2023 , reaching a mark of 661.3 million dollars [5]. One of the key factors driving the global development of cellulose nanostructures is the growing demand for sustainable products. These aspects have encouraged new studies to understand the reactivity of cellulose nanofibers with proteins, fats, enzymes, as well as animal cells and tissues [6,7]. Overall, nanotechnology improves the use of plant by-products in a sustainable manner by increasing the dietary fiber utilization capacity, thus benefiting animal production.

Nanofibers have been reported to exert healing effects [8,9], bone regeneration $[10,11]$, and anti-inflammatory effects on intestinal epithelial cells, indicating their biomedical applications [12]. Further, they show increased absorption in enterocytes, mediated by specific transporters $[13,14]$. However, the application of nanotechnology in animal nutrition is relatively recent, with few studies on the potential effects of nanoparticles, and their ability to react with bacteria in the digestive tract, based on their catalytic, magnetic properties, and reactivity [15]. In the previous studies $[6,16,17]$, nanofibers from pupunha palm heart were found to increase the body weight of rats by $9 \%$, without any toxic effects to the animals [16], no histopathological changes, and no effect on feed 
consumption [17]. It was observed that serum triglyceride (TG) values were reduced by $36.0 \%$ when $1.0 \% \mathrm{NC}$ was included in the diet of rats [6]. Cellulose nanofibers reduce the contact for the action of lipases, decreasing the digestion and absorption of fats in the small intestine, thereby improving the blood lipid profile. Nanominerals are widely used in diversified sectors, including agriculture, animal, and food systems. These nanominerals have significant growth-promoting, immunomodulatory, antibacterial effects even at much lower doses than the conventional organic and inorganic mineral sources $[18,19]$. In poultry diets, supplementation with nanominerals (selenium, zinc, and chromium) promotes weight gain, egg production, and improved product quality [18]. Nano-selenium and nano-zinc in the diet of laying hens improved egg production [20] and bone strength [21]. In addition, increased body weight and feed efficiency have been reported with the inclusion of nano-chrome in the diet of birds [22]. In broilers, nano-selenium is reported to improve weight gain [23] and meat quality [24], in addition to reducing the negative effects of heat stress [25]. In sheep, supplementation with nano-selenium improved ruminal fermentation and volatile fatty acids (VFA) synthesis [26], thus increasing microbial activity and the use of nutrients from the diet [27]. Supplementation of chitosan nanoparticles in the diet of piglets improved the average daily weight gain of the animals by $38.31 \mathrm{~g}$ [28]. In an in vitro study on esophageal cells from rats [29], it was observed that the adsorbent effect of NC reached up to $85 \%$ for aflatoxin $\mathrm{B}_{1}$ in different foodstuffs (hazelnut, pistachio, almond, walnut, wheat, and rice), without any toxic effect on the esophagus. Considering the health benefits that can be achieved with nanofibers supplied from abundant and renewable natural sources, the use of agro-industrial waste contributes to sustainability in animal production and nutrition systems with increased productivity and reduced environmental impact.

Within this context, the use of nanotechnology to obtain nanofibers with different functional properties is promising, as they present increased reactivity and can interact with the intestinal epithelium layer, thus improving the use of fibers, which are mostly indigestible by monogastric animals. Nanofibers can help protect the mucosa and improve intestinal health and microbial fermentation in the large intestine. Therefore, production-processing safety in relation to nanofibers must be understood for contributing to food production worldwide. Nanotechnology can thus be used to improve the nutritional aspect of fibers and positively impact the intestinal health of animals.

\section{Application of Cellulose Nanofibers in Animal Nutrition}

Fiber intake is well known to benefit animal health through improved blood lipid profiles, improved intestinal health, and efficient use of the diet [14,30-32], resulting in enhanced performance and productivity rates. Considering the benefits of dietary fiber, several studies have demonstrated the effects of using cellulose nanofibers as an alternative ingredient to improve diet quality and acceptability and promote intestinal health.

Cellulose nanofibers are a new material with excellent potential for use in diets because of their reactive properties and resistance to gastric digestion $[33,34]$, which may favor the integrity of the intestinal mucosa, modulate the digestive tract microbiota, and ensure a healthy balance in the body. Recently, nanofibers were tested as a potential food ingredient for rats, and they were found to maintain adequate growth. Growing rats fed with $7 \%, 14 \%$, and $21 \%$ of nanofibers from the pupunha palm heart sheath showed good acceptability to the feed, without displaying any signs of toxicity, such as vomiting and/or diarrhea [16]. In another study on rats, using $21 \%$ of pupunha NC as a potential food ingredient, the performance and structural histology of the liver, glycemia, cholesterol, and TG values remained unchanged [17].

Another effect related to plant-based nanostructures (nano-celluloses) was the mycotoxin adsorbent potential (aflatoxin $\mathrm{B}_{1}$ ) and reduced contamination in rat esophageal cells in vitro. Adsorption of aflatoxin $\mathrm{B}_{1}$, attributed to its reactive capacity, has also been confirmed in different foodstuffs such as hazelnuts, pistachios, nuts, and rice [28]. In addition, an in vitro study indicated that $\mathrm{NC}$ concentrations above $1000 \mu \mathrm{g} / \mathrm{mL}$ can induce metabolic disturbance in the cell wall and cell membrane of bacterial and fungal strains by forming a protective barrier in the bacterial cell wall and reducing the metabolism and exchange of cytoplasmic material [35]. It is hypothesized that NC does not cause disturbances or changes in the bacterial cytoplasm but can inhibit the growth of bacteria and fungi, including Escherichia coli, Streptococcus aureus, and Aspergillus niger.

Intake of cellulose nanofibers can prevent excess fat accumulation in the blood; for instance, an in vivo study in rats fed with a diet including $1.0 \%$ of $\mathrm{NC}$, showed that the serum TGs were reduced by $36.0 \%$. In an in vitro study, a $48.4 \%$ reduction was observed in the digestion and absorption of free fatty acids and TGs in the small intestine of an acellular simulated gastrointestinal tract (GIT) [6], thereby avoiding excess body fat. This favors the improvement of blood lipid profiles, with an important contribution to individual health, similar to the use of fibers in the diet [30]. These studies suggest that nanofibers react with digestive enzymes, proteins, and dietary fats during digestion, an important feature to improve the applicability of plant-based nanostructures in animal diets.

\section{Digestion, Absorption, and Metabolism of Cellulose Nanofibers in the GIT}

After ingestion, nanofibers are exposed to various $\mathrm{pH}$ conditions and chemical reactions during the 
digestive process in the mouth, stomach, small intestine, and large intestine. Cellulose nanofibers show chemical differences in their structures, which may be related to the surface area per unit mass or specific surface area [6], with increased absorption during passage through the digestive tract.

The ingested nanoparticles, due to their physicochemical properties and structural characteristics, act in different ways in the GIT of animals. Cellulose nanofibers can influence: (i) Interactions between the components of gastrointestinal fluids (such as enzymes, bile salts, phospholipids, and biopolymers); (ii) the formation of protein and fat aggregates and stability within different regions of the GIT; (iii) the passage of compounds through the mucus layer that lines the intestinal wall; (iv) transport into the cells through the epithelium; and (v) interactions between the fermenting bacteria of the cecum and colon in the large intestine [36-38].

In the mouth, nanoparticles are exposed to mastication whereby positively charged particles interact with saliva proteins [38]. In the stomach, absorption and hydrolysis by digestive enzymes are unlikely due to the thick mucus layer and $\mathrm{pH}$ of the environment [33], which prevents the passage of nanoparticles into the bloodstream. Cellulose nanocrystals (CNCs) can reduce the kinetics or initial enzymatic reaction time of proteolytic enzymes to digest proteins in the gastric phase [39].

During passage through the small intestine, nanofibers can penetrate the mucus layer [34] and become desulfated [7]. Furthermore, negatively charged particles can aggregate with other structures [40], facilitating permeability through the digestive tube. In the large intestine, nanoparticles are suggested to interact with the microbiota present, altering the synthesis and metabolism of VFA [41].

The formation of nanofiber aggregates with proteins and fats can alter the action of proteases and lipases in the digestive process [6]. It has been reported that $\mathrm{CNCs}$ can form a coating around fat droplets, reducing the solubilization of fats by bile salts (necessary for fixing lipase in digestion). This results in a decreased available surface area for lipase binding and action $[39,42]$, thus reducing the absorption of lipids [3].

The absorption of nanoparticles in the GIT depends on their diffusion through the mucosal lining, initial contact with the intestinal epithelium, and the process of capture by enzymes and translocation through the cell [43]. However, smaller anionic particles with negative polarity may tend to diffuse through the mucus layer and reach the epithelial surface more easily than larger particles $[34,44]$. The mucus layer throughout the GIT is negatively charged [45], as is sulfated CNCs [40], such as those isolated by chemical processes $\left(\mathrm{H}_{2} \mathrm{SO}_{4}\right)$. Therefore, the mucus layer and digestive tract epithelium are the main barriers to the passage of nanostructures into the bloodstream [44].
Permeability of the tight junctions in the gastrointestinal epithelium can be modulated by specific polymers and simple organic molecules. These polymers can act as tight junction regulators, thus introducing a gateway for many particles such as toxins, metabolites, and nanoparticles [46]. Another possible uptake route is the transcellular route, at the apex of the intestinal epithelium (pinocytosis), transported through the $\mathrm{M}$ cells in the enterocytes (Figure-1), and later released on the basolateral side of the intestinal epithelium [47-49]. In addition, M cells can absorb particles smaller than $200 \mathrm{~nm}$ and can thus absorb nanoparticles, which are smaller in size [50,51]. However, absorption has widely been described in quantitative terms in a previous study [52].

After passing through the intestinal epithelium, $\mathrm{CNCs}$ can bind various blood components (plasma proteins, clotting factors, platelets, and red and white blood cells) depending on their chemical structure, resulting in the translocation of the particles into organs such as the liver, kidneys, and spleen [53-55]. However, the vast majority of CNCs considered to be absorbed by one of the endocytosis processes [34], are transported by the lymphatic system because of the size of these particles, which can pass through the pores of the vascular system [56].

In addition, Koshani and Madadlou [34], reported that it is unlikely that CNCs participate in the primary and secondary metabolic reactions in the liver due to their considerable hydrophilic nature. However, it has been reported that polystyrene nanofibers, administered intravenously to rats, are absorbed by the liver and excreted in the bile, and that smaller particles $(50 \mathrm{~nm})$ are phagocytosed and absorbed by hepatocytes [57]. In another study, systemic distribution of $50 \mathrm{~nm}$ and $100 \mathrm{~nm}$ nanoparticles in the body, liver, spleen, and blood were reported [58]. Thus, the capture and distribution of nanoparticles in the body depend on the surface characteristics and size of the particles [47]. The structure of the CNCs carried through the organism is practically maintained. This peculiarity of nanofibers can assist several reaction processes in the organism because of their reactive capacity [33], differentiating them from any other ingredient used to improve nutrition at present.

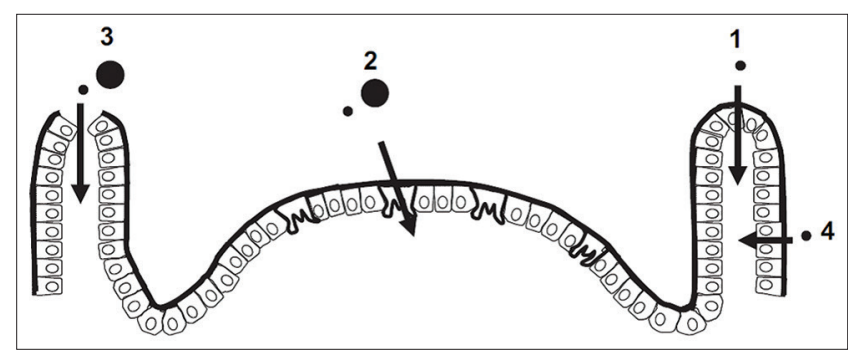

Figure-1: Transcellular route, at the apex of the intestinal epithelium (pinocytosis): (1) Endocytosis. (2) M-cell uptake (transcytosis). (3) Persorption. (4) Putative paracellular uptake [52]. 


\section{Toxicological Studies with Cellulose Nanofibers}

Understanding the potential implications of nanomaterials, whether beneficial or toxicological, is of paramount importance for developing new technologies in animal and human nutrition. No evidence of NC toxicity has been found in several models of cell and animal exposure in recent studies $[59,60]$. In in vivo studies, inclusion of up to $21 \%$ of nanofibers from the pupunha palm heart sheath did not cause histopathological changes in the liver, diarrhea, or vomiting $[16,17]$. Likewise, supplementation with $100 \mu \mathrm{g} / \mathrm{mL}$ of cotton cellulose nanofibers showed no cytotoxic effect. However, concentrations of $200,400,800$, and $1000 \mu \mathrm{g} / \mathrm{mL}$ caused cell death in bovine fibroblasts, and high concentrations of CNF (2000 and $5000 \mu \mathrm{g} / \mathrm{mL}$ ) decreased cell viability as well as the expression of molecular markers associated with apoptosis [61]. The cytotoxicity of CNCs is less intense than that exerted by structures such as multiwalled carbon nanotubes and crocidolite asbestos [62]. This makes nanofibers a safer ingredient for innovative technologies in animal nutrition.

Using a THP-1 cell line differentiated from human macrophages to screen for cytotoxicity, reported that unlike carbon nanotubes and zinc oxide, cellulose nanofibers were not cytotoxic (at doses up to $100 \mu \mathrm{g} / \mathrm{mL}$ ) [63]. In another model of triple cell culture of the human epithelial airway, the cotton cellulose nanofibers showed less potential for cytotoxicity in the synthesis of pro-inflammatory responses compared to multi-walled nanotubes and crocidolite asbestos fibers [62]. Moreover, exposure to cotton NFs (50 and $100 \mu \mathrm{g} / \mathrm{mL}$ ) affected the viability and growth of Chlorella vulgaris algae after $24 \mathrm{~h}$ of exposure. Cytotoxic effects can cause cell death by inducing oxidation, altering cell balance, adenosine triphosphate synthesis, and decreasing photosynthetic activity [63], due to gel formation at high concentrations that block gas exchange across the cell membrane.

The distribution of nanoparticles in the bloodstream can induce an increase in the non-specific immune response. The effects of chitosan nanoparticles were evaluated at doses of 100, 200, and $400 \mathrm{mg} / \mathrm{kg}$ on the humoral immune response of growing piglets, and it was observed that the plasma concentrations of $\operatorname{IgA}$ and $\operatorname{IgG}$ immunoglobulin were higher in animals treated with $400 \mathrm{mg}$ of chitosan nanoparticles [28]. Other characteristics such as particle size and distribution, particle load, and surface area should also be considered when describing the dosage and degree of toxicity of these materials [43]. Considering these results, replacing dietary fiber with cellulose nanofibers may improve the immune status, intestinal microbiota, and performance of animals.

\section{Innovations and Benefits of Using Nanoparticles in Animal Nutrition}

Despite being relatively new to the field, studies have shown beneficial effects of the addition of nanofibers in animal diets (Table-1), highlighting the advantages and benefits of their application $[6,17,63]$, which makes this theme innovative and extremely important for sustainable animal production in an increasingly competitive market.

In animal nutrition, application of cellulose nanofibers represents a major advantage. Cellulose nanofibers have a strong ability to penetrate intestinal epithelial cells, due to their size and total surface area, with anti-inflammatory effects, as reported previously $[13,14,43,64]$. In addition, nanofibers present increased absorption in enterocytes, mediated by specific transporters. It has thus been increasingly accepted that nanofibers can help improve intestinal morphology, as they prevent shortening of villi and tissue injuries, hence improving animal performance.

Satisfactory results were obtained by Andrade et al. [17] who observed a $10 \%$ increase in the body weight of rats, with no changes in feed intake or damage to the animals' organs. Mendes [16] observed good acceptability of the diet and increased body mass in rats by including $14 \%$ of nano-pupunha in their feed. In addition, no toxic or harmful effects to the animals were observed. $\mathrm{Xu}$ et al. [28] found that supplementation with $400 \mathrm{mg} / \mathrm{kg}$ of chitosan nanoparticles increased the average daily weight gain of piglets by $38.82 \mathrm{~g}$.

Other studies indicate that nanotechnology applied to improve animal nutrition and productivity has provided great advances. Radwan et al. [20] observed that $0.25 \mathrm{ppm}$ of nano-selenium in the diet of laying hens increased egg production and feed conversion. In a study by Abedini et al. [21], $80 \mathrm{mg}$ of zinc oxide nanoparticles in the diet of laying hens improved feed consumption, egg mass, and shell resistance. Sirirat et al. [22] observed that supplementation with chromium nanoparticles $(80 \mathrm{~nm})$ improved egg quality and increased mineral retention $(\mathrm{Cr}, \mathrm{Cu}, \mathrm{Ca}$, $\mathrm{Fe}$, and $\mathrm{P}$ ) in the liver of birds.

In a study by Ahmadi et al. [24], inclusion of nano-selenium significantly improved weight gain and feed conversion. Furthermore, the use of energy and protein in the diet was more efficient in groups supplemented with $0.3 \mathrm{mg}$ of nano-selenium. Cai et al. [23] found that nano-selenium supplementation at a concentration of $0.3 \mathrm{mg}$ in the broiler diet improved meat quality. According to El-Deep et al. [25], $0.3 \mathrm{mg}$ of nano-selenium reduced the negative effects of heat stress (weight gain, feed intake, feed conversion ratio, breast muscle weight, and abdominal fat weight) in broilers at elevated temperatures $\left(35 \pm 1^{\circ} \mathrm{C}\right)$.

Positive effects of nanotechnology to increase dietary efficiency have also been found in studies with other animal species (sheep). Liguang et al. [26] reported that the inclusion of nano-selenium $(3.0 \mathrm{~g})$ in the diet of male sheep had the ability to regulate rumen $\mathrm{pH}$, decrease the concentration of ammonia $(\mathrm{N})$, and induce increased fiber degradation in the rumen as 
Table-1: Inclusion of nanoparticles in the animal diet as ingredients, and the impacts on animal production.

\begin{tabular}{|c|c|c|c|c|c|c|c|c|c|}
\hline Reference & Year & $\begin{array}{l}\text { Types of } \\
\text { nanostructures }\end{array}$ & $\begin{array}{l}\text { Size } \\
(\mathrm{nm})\end{array}$ & Dose & $\begin{array}{l}\text { Animal } \\
\text { species }\end{array}$ & $\begin{array}{l}\text { Performance } \\
\text { and productivity }\end{array}$ & $\begin{array}{l}\text { Other } \\
\text { benefit }\end{array}$ & $\begin{array}{l}\text { Quality } \\
\text { of the } \\
\text { product }\end{array}$ & Conclusion \\
\hline [26] & 2011 & Nano-selenium & 80 & $3.00 \mathrm{~g}$ & Sheep & $\begin{array}{l}<\mathrm{pH} \\
\text { ruminal<ammonia } \\
\text { concentration/N }\end{array}$ & & $\mathrm{N} / \mathrm{A}$ & $\begin{array}{l}\text { > Use of feed } \\
\text { nutrients }\end{array}$ \\
\hline [27] & 2012 & Nano-selenium & 80 & $4.00 \mathrm{~g}$ & Sheep & $\begin{array}{l}<\mathrm{pH} \\
\text { ruminal<ammonia } \\
\text { concentration }\end{array}$ & $\begin{array}{l}\text { Increased } \\
\text { AGVs }\end{array}$ & $\mathrm{N} / \mathrm{A}$ & $\begin{array}{l}\text { > Digestibility } \\
\text { of MS > Feed } \\
\text { efficiency }\end{array}$ \\
\hline [23] & 2012 & Nano-selenium & 80 & $0.03 \mathrm{~g}$ & Broilers & $>$ Meat quality & $\begin{array}{l}\text { Antioxidant } \\
\text { effect }\end{array}$ & $\mathrm{N} / \mathrm{A}$ & $\begin{array}{l}>1.0 \mathrm{mg} \\
\text { can cause } \\
\text { performance } \\
\text { losses }\end{array}$ \\
\hline$[16]$ & 2013 & $\begin{array}{l}\text { Pupunha } \\
\text { nanofibers }\end{array}$ & $<100$ & $14 \%$ & Rats & $\begin{array}{l}9 \% \text { increase in } \\
\text { body mass }\end{array}$ & $\begin{array}{l}\text { No toxic } \\
\text { effects } \\
\text { Good diet } \\
\text { acceptability }\end{array}$ & N/A & $\begin{array}{l}\text { > Body } \\
\text { weight, } \\
\text { homeostatic } \\
\text { body balance }\end{array}$ \\
\hline$[22]$ & 2013 & Nano-chromium & 80 & $\begin{array}{c}0.0005 \\
g\end{array}$ & $\begin{array}{l}\text { Laying } \\
\text { chicken }\end{array}$ & $\begin{array}{l}\text { > Body weight, } \\
\text { feed intake, and } \\
\text { feed efficiency }\end{array}$ & $\begin{array}{l}>\text { Egg } \\
\text { production }\end{array}$ & $\begin{array}{l}\text { > Egg } \\
\text { quality }\end{array}$ & $\begin{array}{l}\text { > Laying } \\
\text { productivity }\end{array}$ \\
\hline [20] & 2015 & Nano-selenium & $<80$ & $\begin{array}{c}0.00025 \\
g\end{array}$ & $\begin{array}{l}\text { Laying } \\
\text { chicken }\end{array}$ & $\begin{array}{l}>\text { Egg } \\
\text { production > Food } \\
\text { conversion }\end{array}$ & $\begin{array}{l}\text { >Antioxidant } \\
\text { enzymes } \\
\text { activity }\end{array}$ & $\begin{array}{l}\text { Improved } \\
\text { egg } \\
\text { quality }\end{array}$ & $\begin{array}{l}\text { > Performance } \\
\text { and } \\
\text { productivity }\end{array}$ \\
\hline$[17]$ & 2015 & $\begin{array}{l}\text { Pupunha } \\
\text { nano-cellulose }\end{array}$ & $<100$ & $14 \%$ & Rats & $\begin{array}{l}10 \% \text { increase in } \\
\text { body mass }\end{array}$ & $\begin{array}{l}<\text { Diet } \\
\text { consumption; } \\
\text { no toxic } \\
\text { effects }\end{array}$ & $\mathrm{N} / \mathrm{A}$ & $\begin{array}{l}\text { > Body } \\
\text { weight, } \\
\text { without } \\
\text { damage to } \\
\text { health }\end{array}$ \\
\hline$[25]$ & 2016 & Nano-selenium & 80 & $0.003 \mathrm{~g}$ & Broilers & $\mathrm{N} / \mathrm{O}$ & $\begin{array}{l}<\text { Thermal } \\
\text { stress effect }\end{array}$ & $\mathrm{N} / \mathrm{A}$ & $\begin{array}{l}\text { Assists in } \\
\text { body balance }\end{array}$ \\
\hline$[24]$ & 2018 & Nano-selenium & 80 & $0.003 \mathrm{~g}$ & Broilers & $\begin{array}{l}\text { >Productivity } \\
\text { indexes > Food } \\
\text { conversion }\end{array}$ & $\begin{array}{l}\text { > Weight of } \\
\text { breast and } \\
\text { drumstick }\end{array}$ & $\begin{array}{l}\text { > Carcass } \\
\text { quality }\end{array}$ & $\begin{array}{l}\text { > Chicken } \\
\text { development }\end{array}$ \\
\hline$[21]$ & 2018 & Nano-zinc & $<80$ & $0.080 \mathrm{~g}$ & $\begin{array}{l}\text { Laying } \\
\text { chicken }\end{array}$ & $\begin{array}{l}<\text { Feed } \\
\text { consumption }>\text { Egg } \\
\text { mass }>\text { Shell } \\
\text { strength }\end{array}$ & $\begin{array}{l}\text { > Bone } \\
\text { resistance }\end{array}$ & $\begin{array}{l}\text { > Egg } \\
\text { quality }\end{array}$ & $\begin{array}{l}\text { > Productive } \\
\text { performance } \\
\text { of layers }\end{array}$ \\
\hline$[28]$ & 2020 & $\begin{array}{l}\text { Chitosan } \\
\text { nanoparticles }\end{array}$ & 50 & $0.04 \mathrm{~g}$ & Piglets & $\begin{array}{l}\text { Increase of } 38.82 \\
\text { g GMD weight }\end{array}$ & $\begin{array}{l}\text { Increase of } \\
\text { IgA and IgG }\end{array}$ & N/A & $\begin{array}{l}\text { > Performance } \\
\text { and the piglet } \\
\text { immune } \\
\text { system }\end{array}$ \\
\hline
\end{tabular}

The studies are structured in chronological order. The table shows the main results related to the parameters studied, including improved performance, conversion and feed efficiency, cytotoxicity, oxidative stress, and improved quality of products of animal origin. The signs: <is equal to lesser or worse; >is equal to greater or better; N/A=Not analyzed, $\mathrm{N} / \mathrm{O}=$ Not observed. The final column highlights a succinct consideration of the results of the referenced studies

well as improve the use of protein. Xun et al. [27] showed that supplementation of the sheep diet with $4 \mathrm{~g}$ of nano-selenium reduced the concentration of ammonia in the rumen and improved the digestion of NDF and protein, contributing to increased production efficiency. Thus, the authors highlighted that nanominerals can be used as the preferred source of minerals in animal nutrition, without weakening animal performance. According to studies performed by our team (unpublished results), replacement of $50 \%$ of the dietary fiber by pupunha palm nanofibers improved the performance and intestinal health of rabbits, in addition to decreasing the number of enterobacteria in the cecum of growing rabbits.

There are many positive effects of nanotechnology, in improving animal nutrition by increasing the use of coproducts and the efficiency of dietary ingredients, thus benefiting animal performance. Cellulose nanofibers have chemical characteristics, such as long chains, a large surface area, and hydrogen bonds, which increase their reactivity [7]. These characteristics can modulate fermentation and the microbiota in the digestive tract without any toxicological effects, and still provide benefits to animal performance. However, new research must be conducted to improve the applicability of nanofibers as an ingredient, obtained from cellulose, one of the most abundant sources on the planet.

\section{Conclusion}

The utilization of natural resources in a sustainable manner favors the global economy and reduces the environmental impacts of the agricultural industry, which benefits human health and animal production. Nanotechnology can positively impact the animal production chain, with benefits to the intestinal health of animals, increased productivity, and reduced environmental impacts. 


\section{Authors' Contributions}

CA and LBC: Conception of the review. GRO and CA: Collected literature and wrote the manuscript. CA, CSS, and LBC: Corrected the manuscript. All authors read and approved the final manuscript.

\section{Acknowledgments}

This study was funded by the Coordenação de Aperfeiçoamento de Pessoal de Nível Superior (CAPES), Brazil (Finance Code 001), and the Conselho Nacional de Desenvolvimento Científico e Tecnológico (CNPq), Brazil (Finance Code 444620/2014-1).

\section{Competing Interests} interests.

The authors declare that they have no competing

\section{Publisher's Note}

Veterinary World remains neutral with regard to jurisdictional claims in published institutional affiliation.

\section{References}

1. Ventura, C., Pinto, F., Lourenço, A.F., Ferreira, P.J.T., Louro, H. and Silva, M.J. (2020) On the toxicity of cellulose nanocrystals and nanofibrils in animal and cellular models. Cellulose, 27(10): 5509-5544.

2. Seabra, A.B., Bernardes, J.S., Fávaro, W.J., Paula, A.J. and Durán, N. (2018) Cellulose nanocrystals as carriers in medicine and their toxicities: A review. Carbohydr Polym., 181: 514-527.

3. Wang, Y., Wang, W., Jia, H., Gao, G., Wang, X., Zhang, $X$. and Wang, Y. (2018) Using cellulose nanofibers and its palm oil Pickering emulsion as fat substitutes in emulsified sausage. J. Food Sci., 83(6): 2017-2055.

4. Pacheco-Torgal, F. and Jalali, S. (2011) Nanotechnology: Advantages and drawbacks in the field of construction and building materials. Constr. Build. Mater., 25(2): 582-590.

5. Research and Markets. (2018) Nanocellulose Market by Type, Application, and Region Global Forecast to 2023, Dublin. p4659472. Available from: https://www.researchandmarkets.com/research/jgxkwd/650_mn?w=5 Retrieved on 13-01-2021.

6. DeLoid, G.M., Sohal, I.S., Lorente, L.R., Molina, R.M., Pyrgiotakis, G., Stevanovic, A., Zhang, R., Mcclements, D.J., Geitner, N.K., Bousfield, D.W., Woei, N.G.K., Loo, S.C.J., Bell, D.C., Rain, J. and Demokritou, J. (2018) Reducing intestinal digestion and absorption of fat using a nature-derived biopolymer: Interference of triglyceride hydrolysis by nanocellulose. J. Am. Chem. Soc., 12(7): 6469-6479.

7. Habibi, Y., Lucia, L.A. and Rojas, O.J. (2010) Cellulose nanocrystals: Chemistry, self-assembly, and applications. Chem. Rev., 110(6): 3479-3500.

8. Babaeijandaghi, F., Shabani, I., Seyedjafari, E., Naraghi, Z.S., Vasei, M., Haddadi-Asl, V., Hesari, K.K. and Soleimani, M. (2010) Accelerated epidermal regeneration and improved dermal reconstruction achieved by polyethersulfone nanofibers. Tissue Eng. Part A, 16(11): 3527-3536.

9. Steffens, D., Leonardi, D., Soster, P.R.L., Lersch, M., Rosa, A., Crestani, T., Scher, C., Morais, M.G., Costa, J.A.V. and Pranke, P. (2014) Development of a new nanofiber scaffold for use with stem cells in a third degree burn animal model. Burns, 40(8): 1650-1660.

10. Berner, A., Boerckel, J.D., Saifzadeh, S., Steck, R., Ren, J., Vaquette, J., Zhang, J.Q., Nerlich, M., Guldberg, R.E., Hutmacher, W. and Woodruff, M.A. (2012) Biomimetic tubular nanofiber mesh and platelet rich plasma-mediated delivery of BMP-7 for large bone defect regeneration. Cell Tissue Res., 347(3): 603-612.

11. Boerckel, J.D., Kolambkar, Y.M., Dupont, K.M., Uhrig, B.A., Phelps, E.A., Stevens, H.Y., Garcia, A.J. and Guldberg, R.E. (2011) Effects of protein dose and delivery system on BMP-mediated bone regeneration. Biomaterials, 32(22): 5241-5251.

12. Krishnamoorthy, S. (2015) Nanostructured sensors for biomedical applications a current perspective. Curr. Opin. Biotechnol., 34: 118-124.

13. Azuma, K., Osaki, T., Ifuku, S., Saimoto, H., Morimoto, M., Takashima, O., Tsuka, T., Imagawa, T., Okamoto, Y. and Minami, S. (2014) Anti-inflammatory effects of cellulose nanofiber made from pear in inflammatory bowel disease model. Bioacti. Carbohydr. Diet. Fiber, 3(1): 1-10.

14. Chen, W., Li, D., Ei-Shanshory, A., El-Newehy, M., El-Hamshary, H.A., Al-Deyab, S.S., He, C. and Mo, X. (2015) Dexamethasone loaded core-shell SF/PEO nanofibers via green electrospinning reduced endothelial cells inflammatory damage. Colloids Surfaces B Biointerfaces, 126: 561-568.

15. Shatkin, J.A. (2008) Perspectives in Nanotechnology: Nanotechnology Health and Environmental Risks. CRC Press, New York. p194.

16. Mendes, D. (2013) Obtenção de nanofibrilas de celulose a partir de resíduo de bainha de pupunha e sua avaliação toxicológica como suplemento de fibras na alimentação animal. Biology, 2013: 85612981.

17. Andrade, D.R.M., Mendonça, M.H., Helm, C.V., Magalhães, W.L.E., Muniz, G.I.B. and Kestur, S.G. (2015) Assessment of nano cellulose from peach palm residue as a potential food additive: Part II: Preliminary studies. J. Food Sci. Technol., 52(9): 5641-5650.

18. Swain, P.S., Rajendran, D., Rao, S.B.N. and Dominic, G. (2015) Preparation and effects of nano mineral particle feeding in livestock: A review. Vet. World, 8(7): 888-891.

19. Joshua, P.P., Valli, C. and Balakrishnan, V. (2016) Effect of in ovo supplementation of nano forms of zinc, copper, and selenium on post-hatch performance of broiler chicken. Vet. World, 9(3): 287-294.

20. Radwan, N.L., Eldin, T.S., El-Zaiat, A. and Mostafa, M.A. (2015) Effect of dietary nano-selenium supplementation on selenium content and oxidative stability in table eggs and productive performance of laying hens. Int. J. Poult. Sci., 14(3): 161-176.A

21. Abedini, M. Shariatmadari, F., Torshizi, M.A.K. and Ahmadi, H. (2018) "Effects of zinc oxidenanoparticles on performance, egg quality, tissue zinc content, bone parameters, and antioxidative status in laying hens. Biol. Trace Elem. Res., 184(1): 259-267.

22. Sirirat, N., Lu, J.J., Hung, A.T.Y. and Lien, T.F. (2013) Effect of different levels of nanoparticles chromium picolinate supplementation on performance, egg quality, mineral retention, and tissues minerals accumulation in layer chickens. J. Agric. Sci., 5(2): 150-159.

23. Cai, S.J., Wu, C.X., Gong, L.M., Song, T., Wu, H. and Zhang, L.Y. (2012) Effects of nano-selenium on performance, meat quality, immune function, oxidation resistance, and tissue selenium content in broilers. Poult. Sci., 91(10): 2532-2539.

24. Ahmadi, M., Ahmadian, A. and Seidavi, A.R. (2018) Effect of different levels of nano-selenium on performance, blood parameters, immunity and carcass characteristics of broiler chickens. Poult. Sci. J., 6(1): 99-108.

25. El-Deep, M.H., Ijiri, D., Ebeid, T.A. and Ohtsuka, A. (2016) Effects of dietary nano-selenium supplementation on growth performance, antioxidative status, and immunity in broiler chickens under thermoneutral and high ambient temperature conditions. J. Poult. Sci., 53(4): 274-283.

26. Liguang, S., Xun, W., Yue, W., Zhang, C., Ren, Y., Liu, Q., Wang, Q. and Shi, L. (2011) Effect of elemental 
nano-selenium on feed digestibility, rumen fermentation, and purine derivatives in sheep. Anim. Feed Sci. Technol., 163(2-4): 136-142.

27. Xun, W., Shi, L., Yue, W., Zhang, C., Re, Y. and Liu, Q. (2012) Effect of high-dose nano- selenium and selenium-yeast on feed digestibility, rumen fermentation, and purine derivates in sheep. Biol. Trace Elem. Res., 150(1-3): 130-136.

28. Xu, Y., Mao, H., Yang, C., Du, H., Wang, H. and Tu, J. (2020) Effects of chitosan nanoparticle supplementation on growth performance, humoral immunity, gut microbiota and immune responses after lipopolysaccharide challenge in weaned pigs. J. Anim. Physiol. Anim. Nutr., 104(2): 597-605.

29. Jebali, A., Ardakani, S.A.Y., Sedighi, N. and Hekmatimoghaddam, S. (2015) Nanocellulose conjugated with retinoic acid: Its capability to adsorb aflatoxin $\mathrm{B}_{1}$. Cellulose, 22(1): 363-372.

30. Mira, G.S., Graf, H. and Cândido, L.M.B. (2009) Visão retrospectiva em fibras alimentares com ênfase em beta-glucanas no tratamento do diabetes. Braz. J. Pharm. Sci., 45(1): 11-20.

31. Díez, I., Eronen, P., Österberg, M., Linder, M.B, Ikkala, O. and Ras, R.H.A. (2011) Functionalization of nanofibrillated cellulose with silver nanoclusters: Fluorescence and antibacterial activity. Macromol. Biosci., 11(9): 1185-1191.

32. Knudsen, K.E.B. (1997) Carbohydrate and lignin contents of plant materials used in animal feeding. Anim. Feed Sci. Technol., 67(4): 319-338.

33. Cone, R.A. (2009) Barrier properties of mucus. Adv. Drug Deliv. Rev., 61(2): 75-85.

34. Koshani, R. and Madadlou, A. (2018) A viewpoint on the gastrointestinal fate of cellulose nanocrystals. Trends Food Sci. Technol., 71: 268-273.

35. Jebali, A., Hekmatimoghaddam, S., Behzadi, A., Rezapor, I., Mohammadi, B.H., Jasemizad, T. and Sayadi, M. (2013) Antimicrobial activity of nanocellulose conjugated with allicin and lysozyme. Cellulose, 20: 2897-2907.

36. Bellmann, S., Carlander, D., Fasano, A., Momcilovic, D., Scimeca, J.A., Waldman, W.J., Gombau, L., Tsytsikova, L., Canady, R., Pereira, D.I.A. and Lefebvre, D.E. (2015) Mammalian gastrointestinal tract parameters modulating the integrity, surface properties, and absorption of food-relevant nanomaterials. Wiley Interdiscip. Rev. Nanomed. Nanobiotechnol., 7(5): 609-622.

37. Ensign, L.M., Cone, R. and Hanes, J. (2012) Oral drug delivery with polymeric nanoparticles: the gastrointestinal mucus barriers. Adv. Drug Deliv. Rev., 64(6): 557-570.

38. Roblegg, E., Frohlich, E., Meindl, C., Teubl, B., Zaversky, M. and Zimmer, A. (2012) Evaluation of a physiological in vitro system to study the transport of nanoparticles through the buccal mucosa. Nanotoxicology, 6(4): 399-413.

39. Sarkar, A., Zhang, S., Murray, B., Russell, J.A. and Boxal, S. (2017) Modulating in vitro gastric digestion of emulsions using composite whey protein-cellulose nanocrystal interfaces. Colloids Surf. B. Biointerfaces, 158: 137-146.

40. Roman, M. (2015) Toxicity of cellulose nanocrystals: A review. Ind. Biotechnol., 11(1): 25-33.

41. Bu, Q., Yan, G, Deng, P., Peng, F., Lin, H. and Xu, Y. (2010) NMR-based metabonomic study of the sub-acute toxicity of titanium dioxide nanoparticles in rats after oral administration. Nanotechnology, 21(12): 125105.

42. Sarkar, A., Li, H., Cray, D. and Boxa, S. (2018) Composite whey protein cellulose nanocrystals at oil-water interface: Towards delaying lipid digestion. Food Hydrocoll., 77: 436-444.

43. Bouwmeester, H., Dekkers, S., Noordam, M.Y., Hagens, W.I., Bulder, A.S., Heer, C., Voorde, S.E.C., Wijnhoven, S.W.P., Marvin, H.J.P. and Sips, A.J.A. (2009) Review of health safety aspects of nanotechnologies in food production. Regul. Toxicol. Pharmacol., 53(1): 52-62.
44. Szentkuti, L. (1997) Light microscopical observations on luminally administered dyes, dextrans, nanospheres and microspheres in the pre-epithelial mucus gel layer of the rat distal colon. J. Controll. Release, 46(3): 233-242.

45. Crater, J.S. and Carrier, R.L. (2010) Barrier properties of gastrointestinal mucus to nanoparticle transport. Macromol. Biosci., 10(12): 1473-1483.

46. Salamat-Miller, N. and Johnston, J.P. (2005) Current strategies used to enhance the paracellular transport of therapeutic polypeptides across the intestinal epithelium. Int. J. Pharm., 294(1-2): 201-216.

47. Hoet, P.H.M., Brüske-Hohlfeld, I. and Salata, O.V. (2004) Nanoparticles known and unknown health risks. J. Nanobiotechnol., 2(1): 12.

48. Florence, A.T. (2005) Nanoparticle uptake by the oral route: Fulfilling its potential. Drug Discov. Today Technol., 2(1): 75-81.

49. Des Rieux, A., Fievez, V., Garinot, M., Schneider, Y.J. and Preat, V. (2006) Nanoparticles as potential oral delivery systems of proteins and vaccines: A mechanistic approach. J. Control. Release, 116(1): 1-27.

50. Gebert, A., Rothkötter, H.J. and Pabst, R. (1996) M cells in Peyer's patches of the intestine. Int. Rev. Cytol., 167: 91-159.

51. Rieux, A., Fieveza, V., Theate, I., Mastd, J., Preat, V. and Schneider, Y.J. (2007) An improved in vitro model of human intestinal follicle-associated epithelium to study nanoparticle transport by M cells. Eur. J. Pharm. Sci., 30(5): 380-391.

52. Powell, J.J., Faria, N., Thomas-McKay, E. and Pele, L.C. (2010) Origin and fate of dietary nanoparticles and microparticles in the gastrointestinal tract. J. Autoimmun., 34(3): J226-J233.

53. Nemmar, A., Hoet, P.H.M., Vanquickenborne, B., Dinsdale, D., Thomeer, M., Hoylaerts, M.F., Vanbilloen, H., Mortelmans, L. and Nemery, B. (2002) Passage of inhaled particles into the blood circulation in humans. Circulation, 105(4): 411-414.

54. Dobrovolskaia, M. (2007) Immunological properties of engineered nanomaterials. Nat. Nanotechnol., 2(8): 469-478.

55. Letchford, K. and Burt, H. (2014) A review of the formation and classification of amphiphilic block copolymer nanoparticulate structures: Micelles, nanospheres, nanocapsules and polymersomes. Eur. J. Pharm. Biopharm., 65(3): 259-269.

56. Pawar, V.K., Singh, Y., Meher, J.G., Gupta, S. and Chourasia, M.K. (2014) Engineered nanocrystal technology: In-vivo fate, targeting and applications in drug delivery. J. Control. Release, 183: 51-66.

57. Ogawara, K., Yoshida, M., Higaki, K., Kimura, T., Shiraishi, K., Nishikawa, M., Takakura, Y. and Hashida, M. (1999) Hepatic uptake of polystyrene microspheres in rats: Effect of particle size on intrahepatic distribution. J. Control Release, 59(1): 15-22.

58. Jani, P., Halbert, G.W., Lancridge, J. and Florence, A.T. (1990) nanoparticle uptake by the rat gastrointestinal mucosa: Quantitation and particle size dependency. J. Pharm. Pharmacol., 42(12): 821-826.

59. Bhattacharya, K., Kiliç, G., Costa, P.M. and Fadeel, B. (2017) Cytotoxicity screening and cytokine profiling of nineteen nanomaterials enable hazard ranking and grouping based on inflammogenic potential. Nanotoxicology, 11(6): 809-826.

60. Endes, C., Camarero-Espinosa, S., Mueller, S., Foster, E.J., Petri-Fink, A. and Rothen-Rutishauser, B. (2016) A critical review of the current knowledge regarding the biological impact of nanocellulose. J. Nanobiotechnol., 14(78): 1-14.

61. Pereira, M.M., Raposo, N.R.B., Brayner, R., Teixeira, E.M., Oliveira, V., Quintão, C.C.R. and Brandão, H.M. (2013) Cytotoxicity and expression of genes involved in the cellular stress response and apoptosis in mammalian fibroblast exposed to cotton cellulose nanofibers. Nanotechnology, 24(7): 75-103. 
62. Clift, M.J.D., Foster, E.J., Vanhecke, D., Studer, D., Wick, P., Gehr, P., Rothen-Rutishauser, B. and Weder, C. (2011) Investigating the interaction of cellulose nanofibers derived from cotton with a sophisticated 3D human lung cell coculture. Biomacromolecules, 12(10): 3666-3673.

63. Pereira, M.M., Mouton, L., Yéprémian, C., Couté, A., Lo, J., Marconcini, J.M., Ladeira, L.O., Raposo, N.R.B., Brandão, H.M. and Brayner, R. (2014) Ecotoxicological effects of carbon nanotubes and cellulose nanofibers in
Chlorella vulgaris. J. Nanobiotechnol., 12(15): 2-13.

64. Jahreis, G., Wohlgemuth, S., Grünz, G., Martin, L., Knieling, M., Engel, R., Türk, M. and Keller, S. (2013) Dietary crystalline common-, micro-, nanoscale and emulsified nanoscale sitosterol reduce equally the cholesterol pool in guinea pigs, but varying nanosystems result in different sterol concentrations in serosal jejunum. Nanomedicine, 9(7): 1027-1035.

$* * * * * * * *$ 